Arab World English Journal (AWEJ) Volume 12. Number2 June 2021

DOI: https://dx.doi.org/10.24093/awej/vol12no2.24

Pp.348-363

\title{
The Predictive Ability of High School General Point Average, Standardized Test for English Proficiency, and Type of High School to Foresee the Academic Success of Saudi EFL Freshmen
}

\author{
Nayef Alotaibi \\ Department of English Language and Literature College of Languages and \\ Translation, IMSIU, Saudi Arabia
}

Received: 3/30/2021 Accepted: 6/11/2021 Published 6/24/2021

\begin{abstract}
Although many studies have examined the ability of admission tests and High School General Point Averages to predict academic performance, they are not in agreement whether or not, these two measures are an entirely sufficient criterion to foretell college learning success. In addition, there seems to be a gap in the literature concerning using the type of high school (private or public) a student attends as a supportive measure to the two criteria mentioned above. This study tried to answer the research question, which is: to what extent can student's high school point average, admission test, and the type of school he attended predict his academic performance? The research carries a considerable significance as it cast light on some factors that may foretell the academic success of a college student. The study investigated the predictive capability of students' high school general averages, admission test, which is Standardized Test for English Proficiency, and student's type of high school to predict freshmen's academic success as defined by their college General Point Averages at the end of their first year. The present study utilized regression analysis to analyze the data of 100 students who finished their first year at the college of languages and translation, Imam Muhammad ibn Saud Islamic University, Saudi Arabia. The study findings indicated that the admission test was the best predictor for students' performance. In contrast, surprisingly, students' HSGPAs and the type of school they attended had little significance in determining the attainment of college students. Thus, it is suggested that the entry test be considered an essential measure for admission to the Saudi college.
\end{abstract}

Keywords: academic success, criterion, future performance, high school general point average predictive ability, Saudi EFL Freshmen, admission test

Cite as: Alotaibi, N. (2021). The Predictive Ability of High School General Point Average, Standardized Test for English Proficiency, and Type of High School to Foresee the Academic Success of Saudi EFL Freshmen. Arab World English Journal, 12 (2) 348-363.

DOI: https://dx.doi.org/10.24093/awej/vol12no2.24 


\section{Introduction.}

The significance of predictive validity arises when a specific criterion is utilized to predict the likelihood of some future performance. It refers to the extent to which a person's future level on the measure is predicted from prior test performance (Crocker \& Algina, 1986; Messick, 1989). Postsecondary educational counselors and admissions personnel have always been concerned with predicting new students' success in the college-level study (McPherson \& Schapiro, 2008). According to Marsh et al. (2008), many studies have revealed that 70 to 75 per cent of incoming university students who will drop out of college do so in the first year or the second. Thus, great attention is being paid to the ways new learners take when they join colleges and the subsequent difficulties students may encounter in the course of completing their studies (Bracco, 2014; Dadgar, Collins, \& Schaefer, 2015; Scott-Clayton, Crosta, \& Belfield, 2014). A crucial pinpoint in this regard is placing a student in the right college or program that matches his/her learning abilities. To fulfill this target, admission counselors and college officials usually suggest some admission requirements that can foresee the possibility of students' success in the desired college or institute. To save new learners a world of grief and struggle, incoming learners are usually admitted or rejected based on particular cognitive admission criteria. Among these admission requirements are high school grade point average (ACT, 2009; Atkinson \& Geiser, 2009; Silva, 2008; Zwick \& Sklar, 2005) and standardized test scores (Jerald, 2009; Silva, 2008). Clinedinst, Hurley and Hawkins, (2011) argue that grades in college preparatory courses, the strength of the high school curriculum, admission tests, and high school general point averages (HSGPAs) are good indicators of academic success. A survey conducted by the National Association for College Admission Counseling (NACAC) indicated that standardized tests such as SAT and ACT scores are ranked second on the scale of factors considered in admission decisions after high school grades (Hawkins \& Lantz, 2005).

This study is believed to be of great significance for all learning elements (students, students' families, and learning institutions). It can help to reveal some elements that may effectively predict academic success. Thus, students who show better academic preparation in the admission criteria are likely to succeed and complete their college studies with acceptable scores (Radunzel $\&$ Noble, 2012). For learners, this success means that they have achieved a desirable educational goal with fundamental implications for their futures. For colleges and institutions, on the other hand, student success is evidence that their plans and admission policies have been successful. The student's family, on the other hand, will be glad since their son/daughter is going on the right track, and the study expenses spent on him/her have not gone in vain.

The prevailing belief of college admission makers is that a combination of scores of standardized college admission tests, such as Standardized Test for English Proficiency (STEP), and high school grade average can predict students' success in the college-level study (Camara \& Echternacht, 2000, ACT, 2009; Kobrin,, Patterson, Shaw, Mattern, \& Barbuti. 2008; Rothstein, 2004). Admission professionals contend that admission decisions should not be based on a single measure. Researchers repeatedly insist that using more than one admission criterion is more likely to help predict students' success in their first-year study than utilizing a single measure (Sawyer, 2010). Despite being considered the best single predictor of college study success, it is claimed that HSGPA alone cannot be regarded as an adequate criterion for university admission because grading standards vary across high schools and classrooms. In addition, it is usually alleged that some teachers, especially in private schools, feel pressured to give learners high 
grades despite the middling academic level of their students, a phenomenon known as grade inflation. Some high schools, however, may be too rigorous that students have to make excessive efforts to gain high marks. Standardized admission tests, on the other hand, are not immune to deficiencies. They are alleged to be biased and benefit only students who can afford the cost of private lessons to prepare for the test. Although they are known to boost many benefits such as standardization, efficiency, and opportunity, entry tests are also said to do not measure specific academic aspects such as persistence and motivation, and they can only reveal cognitive competence.

The objective of this correlational study is to examine the predictive ability of HSGPAs and an admission test, STEP, to foresee freshmen's performance at the end of their first-year college study. The study also intends to assert/or refute the frequent allegation that graduates of private schools are usually given high grades despite their low academic levels. When joining colleges, these students typically struggle with their study compared with graduates of public schools. Therefore, the type of high school (private or public) attended by the study subjects is also under investigation. The use of these three predictive measures also aims to fill the gap in the literature of admission procedures.

This study aims at investigating the performance of Saudi, male, freshmen via three predictors: HSGPAs, an entry test (STEP), and the type of high school a student graduated from (whether public or private).

To fulfill the study purpose, the present research aims to answer the following research questions:

1. To what extent do students' grades on the university admission test (STEP) predict their firstyear college GPA in the college of languages and translation, IMISU?

2. To extent do students' high school GPAs predict their first-year college GPA?

3. If any, what relationship is there between the type of students' high school (whether public or private) and their first-year college GPA?

\section{Literature Review}

A considerable figure of studies has been conducted to investigate the ability of students' HSGPAs and their scores on the standardized admission tests to predict new students' success in college-level research.

Many studies have consistently demonstrated that entrance test scores and HSGPA records are valid criteria for gauging early college success as measured by first-year college GPA (Allen \& Robbins, 2010; Allen, Robbins, Casillas, \& Oh, 2008; Noble \& Radunzel, 2007; Robbins, Allen, Casillas, Peterson, \& Le, 2006). A huge number of predictive validity studies reveal that HSGPA is the best predictor for first-year college GPA and that the scores of the standardized entrance test do add a statically significant value to the prediction. Therefore, utilizing both measures can make better results than using HSGPA alone. Perfetto (2002) argued, "The combination of high school grades and standardized test scores has been part and parcel of evaluating applicants for admissions" (p. 31). Further, in a study carried out by Westrick, Le, Robbins, Radunsel, and Shmidt (2012) on 50 institutions, they found that the estimated mean 
relationship with first-year college GPA across institutions was 0.51 for the standardized test (ACT) score and 0.58 for HSGPA.

In a review of more than 60 studies, Mathiasen (1984) revealed that HSGPA and standardized admission test scores are the best predictors of college-level performance. They account for nearly $25 \%$ of the variance when predicting first-year college GPA. Furthermore, in a metaanalysis study, Elert (1992) stated that HSGPA was a twice as good a predictor of college performance than college admission test scores, with college entrance scores accounting for approximately 5\% extra variance in the prediction model. The researcher said that the power of college admission tests is in predicting the GPAs of first year, and, after that year, their predictive strength disappears. This conclusion is in line with the findings of the studies mentioned above.

Analysis of research conducted in 2003 on 80000 learners admitted to the University of California revealed that a student's high school GPA is more accurate in predicting student's success than do the admission tests. The research showed that high school grade average consistently predicts a learner's performance for the whole college study period. Moreover, the significance of high school GPA increases during a student's collegial study, which means that the higher the high school GPA a student has, the bigger chance he/she has to be successful at the college level.

A study carried out by Rel Northwest Institute, 2016 investigated the developmental education (remedial, noncredit bearing courses) and college preparedness for new coming students at the University of Alaska and their performance in college English and math courses. The study showed a strong positive correlation between the learner's high school GPA and success in college courses. The research attributed this correlation to the fact that high school GPA considers the features of student's learning such as motivation and academic persistence that cannot be gauged by standardized tests.

In another study that, partly, supports the conclusions of Rel Northwest investigation, and California analysis, Vulperhorst, Lutz, de Klijn, \& van Tartwijk (2018) conducted a study to compare the predictive validity of HSGPAs with three high school subjects to foretell the performance of Dutch pre-university (VWO) and International Baccalaureate (IB) graduates. The study findings revealed that for VOW students' HSGPAs were better predictors of first year and final GPA achievements. For IB graduates, by contrast, the study showed that HSGPA alone was not accurate measure for predicting final year performance. Therefore, after first year, HSGPA should be used in association with fist-year GPA to foretell final GPA achievement. Thus, the study rejected the use of HSGPA as a single measure for future academic success. It can be seen that the findings of this study are in contrast with the results of the two studied above in relation to utilizing HSGPAs as a single admission criterion.

Hiss's (2014) study analyzed student and graduate records from 123000 learners in 33 colleges where SAT or ACT scores are optional entrance criteria. Findings revealed a strong correlation between high school GPA and college GPA. The study also said that students with high scores for admission tests, such as SAT or ACT, and lower high school GPAs strive with lower college performance and lower college graduation rates. 
In two recent studies, Nagy M. and Molontay R. (2021) studied the predictive validity of the Hungarian university entrance score final university achievement. The study concluded that the test is a valid admission criterion and can predict future academic performance of Hungarian university students. The findings of the study also indicated that HSGPA is also a valid predictor of university study success. In the other study, Ali, Ali \& Afzal (2019) examined the predictive validity of a Uniform Entrance Test for health professionals. The study concluded that students' test scores correlate positively with their academic success. The results of these studies are in a stark contradiction with the conclusions of some studies (Camara \& Echternacht, 2000; Geiser \& Santelices, 2006; Hiss \& Franks, 2014).

However, the literature revealed a point of view claiming some drawbacks of the ability of entry tests to significantly predict college success and persistence (Tracey \& Sedlacek, 1984; Levin \& Wyckoff, 1994; Burton \& Ramist, 2001). Adherents of this view contended that these admission tests measure only the test-taker's cognitive skills, and that they do not provide a fair prediction of college performance for learners from minority groups. Supporters of this stand encouraged the utilization of noncognitive predictors (Wigdor \& Garner, 1982; Tinto, 1993; Tracey \& Sedlacek, 1984).

Other studies have also investigated the role of noncognitive predictors of study success, such as metalinguistic skills (Zeegers, 2001), study motivation (Melancon, 2002), and personality characteristics (Ridgell \& Lounsbury, 2004). Further, in a meta-analysis study, Crede and Kuncel (2008) examined the predictive validity of the study habits, skills, and attitude in predicting study success. The results showed that the study habits, skills, and study motivation, among other factors, played a role in the incremental variance (ranging from .04 to .12) in the college level performance beyond HSGPA and standardized test scores.

It can be seen from this presentation that most of the studies suggest that HSGPAs and entry tests can be a reliable measure for detecting the possibility of university students' success. Some studies, however, do not support the use of a single admission criterion, such as HSGPA. Instead, these studies contended that using more than one admission measure is likely to be valid and reliable and can accurately predict the future performance of university students.

\section{The Nature of the Entrance Test (STEP)}

Step (Standardized Test for English Proficiency) is a standardized, 100-grade test recognized by the Saudi National Center for Assessment, under the supervision of the ministry of higher education in Saudi Arabia. It is of an objective nature and assesses four skills: reading comprehension (40) grades, grammatical structure (30), listening comprehension (20) grades, and Writing analysis (10) grades. The test is of medium complexity and is more accessible than TOEFL and IELTS. Incoming students who tend to join the College of Languages and Translation, IMISU, must gain 55 grades or above on the STEP.

\section{Methodology}

This quantitative study concentrated on the students' first-year attainment because it is the best measure for learners' future achievement. It is a significant indicator of students' need for extra support. Further, first-year college GPA is considered a significant predictor of subsequent outcomes such as retention, continued persistence, and degree attainment (Allen, et al., 2008). 


\section{Instruments}

The study used regression analysis to assess the extent to which high school grade point average and standardized exam scores predict performance in college-level courses, and to see if the type of high school a student attends has an impact on his college performance. The dependent variable, students' achievement at the end of their first-college year, is gauged by three academic measures: HSGPA, admission test, and the type of school attended by the student. In Saudi Arabia, HSGPA is calculated out of 100 points, while in IMISU, university GPA is calculated out of 5. Less than 2.75 is considered a poor level, 2.75-3.74 is good, 3.75-4.49 is very good, and 4.50-5 is distinction level.

\section{Participants}

The population of the study is the Saudi EFL, newcomers who completed their first year at the College of Languages and Translation, IMISU, (KSA), and the study subjects are one hundred randomly chosen male, Saudi students. All cohort students completed their first year in the second semester of 2018. Sixty-one learners of the study sample are private school graduates, while thirty-nine graduated from public schools.

\section{Data Collection and procedures}

The study subjects' first-year GPAs and STEP scores were obtained from the students' affairs office at the college of languages and translation, while students' types of high school were obtained from the database of the deanship of admission and registration deanship, IMISU.

\section{Results}

STEP predictability and students' performance

To fulfill the purpose of this analysis, which was to explore the ability of the entrance exam (STEP) to predict first year's performance of the students of the college of languages and translation, IMISU, the necessary statistics were made. The first-year college GPAs of the 100 randomly chosen first-year students and their STEP scores were calculated using the SPSS. Pearson correlation coefficient was employed to find the correlation coefficients of the students' grades. Further, the equation of the simple linear regression was identified to investigate the predictive ability of STEP to foresee freshmen's GPAs, as the following table reveals:

Table 1. Descriptive Statistics

\begin{tabular}{|l|l|l|l|}
\hline & N & Mean & Std. Deviation \\
\hline Year1 & 100 & 3.757 & 0.019 \\
\hline Step & 100 & 72.89 & 12.588 \\
\hline
\end{tabular}

Table 1 shows that the students' number is 100 and their mean on STEP is 72,89 out of 100 , and the standard deviation is 12,588 . The table also indicates that the freshmen's mean of the first-year's GPA is 3.757 out of five, and the standard deviation is 0,719 . The following table shows further data:

Table 2. Correlations

\begin{tabular}{|l|l|l|l|}
\hline \multicolumn{2}{|c|}{} & Year1 & Step \\
\hline Pearson Correlation & Year1 & 1.000 & 0.399 \\
\cline { 2 - 4 } & Step & 0.399 & 1.000 \\
\hline Sig. (1-tailed) & Year1 & & 0.000 \\
\hline Arab World English Journal & \multicolumn{2}{|c|}{ Www.awej.org } & 353 \\
\hline
\end{tabular}

ISSN: 2229-9327 


\begin{tabular}{|l|l|l|l|}
\hline & Step & 0.000 & \\
\hline $\mathbf{N}$ & Year1 & 100 & 100 \\
\cline { 2 - 4 } & Step & 100 & 100 \\
\hline
\end{tabular}

Table two above reveals that the number of study subjects is 100, and the Pearson correlation coefficient of students' first-year GPA and their performance on STEP is 0.399. This shows a strong positive relationship between the two variables, since the value of the correlation coefficient has a statistical significance $(\alpha \geq 0.05)$ because the value of the statistical significance (p-value) is 0.000 , which is less than 0.05 . More information follows in the table below:

Table 3. Model Summary ${ }^{b}$

\begin{tabular}{|l|l|l|l|l|}
\hline Model & & & & $\begin{array}{l}\text { Std. the error of the } \\
\text { Estimate }\end{array}$ \\
\hline 1 & $\mathrm{R}$ & R Square & Adjusted R Square & 0.662 \\
\hline
\end{tabular}

a. Predictors: (Constant), Step

b. Dependent Variable: Year1

Table three indicates that the correlation coefficient $(\mathrm{R})$ is 0.399 , and the square correlation coefficient is 0.159 , which indicates the percentage of variance in the dependent variable (students' first-year GPA), which we can predict by the independent variable (the students' scores on STEP). The square adjusted correlation coefficient is 0.150 , and the value of the estimated error is 0.662 . More data about the variance analysis is in the following table:

Table 4. ANOVA ${ }^{a}$

\begin{tabular}{|l|l|l|l|l|l|l|}
\hline \multicolumn{2}{|l|}{ Model } & Sum of Squares & df & Mean Square & F & Sig. \\
\hline \multirow{4}{*}{1} & Regression & 8.128 & 1 & 8.128 & 18.521 & $0.000^{\mathrm{b}}$ \\
\cline { 2 - 8 } & Residual & 43.007 & 98 & 0.439 & & \\
\cline { 2 - 7 } & Total & 51.134 & 99 & & & \\
\hline
\end{tabular}

a. Dependent Variable: Year1

b. Predictors: (Constant), Step

Table four is concerned with the analysis of variance, used to tell whether or not the level of regression has a statistical significance. Since the p-value is 0.000 , which is less than 0.05 , this means that the regression has a statistical significance $(\alpha \geq 0.01)$, and this indicates that there is a strong relationship between the dependent variable and the independent one. Further data about coefficients follows:

Table 5. Coefficients

\begin{tabular}{|c|c|c|c|c|c|c|}
\hline \multirow{2}{*}{\multicolumn{2}{|c|}{ Model }} & \multicolumn{2}{|c|}{ Unstandardized Coefficients } & $\begin{array}{l}\text { Standardized } \\
\text { Coefficients } \\
\end{array}$ & \multirow[b]{2}{*}{$\mathrm{T}$} & \multirow[b]{2}{*}{ Sig. } \\
\hline & & $\mathrm{B}$ & Std. Error & Beta & & \\
\hline \multirow[t]{2}{*}{1} & (Constant) & 2.098 & 0.391 & & 5.363 & 0.000 \\
\hline & Step & 0.023 & 0.005 & 0.399 & 4.304 & 0.000 \\
\hline
\end{tabular}

a. Dependent Variable: Preparatory

Based on the information offered in table five above, the constant value is 2.098 , and the independent variable is 0.023 . This means that the regression equation is:

$\mathrm{Y}=2.098+0.023(\mathrm{X})$ 
To further make sure that the data we study meets the conditions required when analyzing the linear regression, it is necessary to check the residuals and the graphs, which can tell whether or not those conditions are met.

The following graph represents the regression line with spots on and around that line (standard $p$ plot).

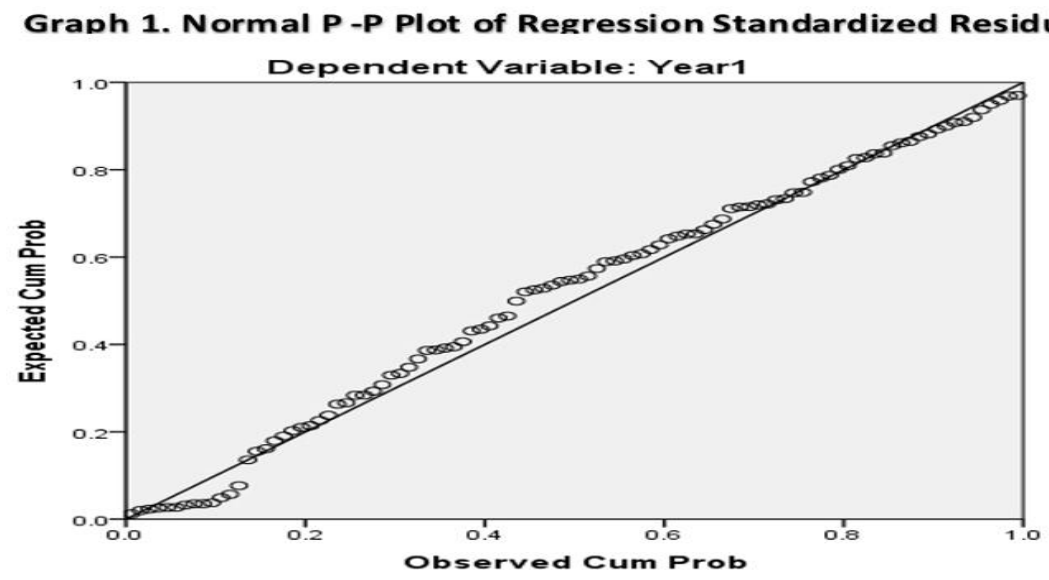

Figure 1. Normal P-P Plot of Regression Standardized Residual

Figure one indicates the data gather around the straight line, and this asserts that the values of the residuals have natural distribution, which is one of the requirements of utilizing the linear regression analysis.

Figure two below shows the form of residuals distribution and the expected values. Because the way of residuals distribution does not follow a specific pattern, this meets the linearity condition, the linear relationship between the dependent and independent variables, which is also one of the linear regression conditions.

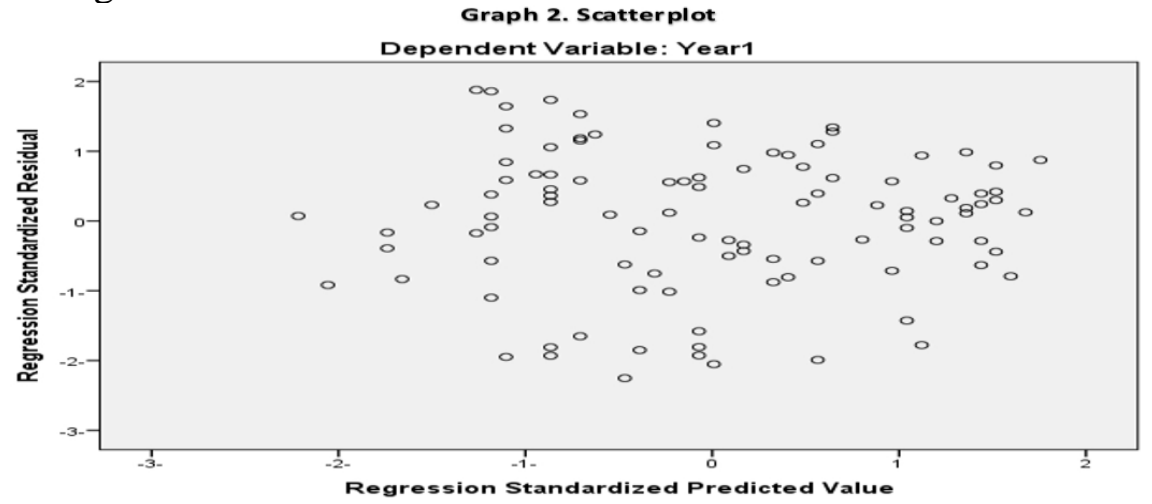

Figure 2. Regression Standardized Value 1

Table 6. The mean and standard Deviation

\begin{tabular}{|c|c|c|c|}
\hline & $\mathrm{N}$ & Mean & Std. Deviation \\
\hline Year1 & 100 & 3.757 & 0.719 \\
\hline Secondary & 100 & 91.400 & 5.935 \\
\hline
\end{tabular}


The predictive ability of students' HSGPAs

This analysis aims at exploring the predictive ability of students' HSGPAs to foresee freshmen's college GPAs, SPSS was used to calculate the high school scores of the 100 selected students. Then, Pearson Correlation Coefficient was employed to find the correlation coefficient among the study subjects. Finally, the equation of the simple regression was calculated to investigate the capability of the HSGPAs to predict students' first-year GPAs.

Table six reveals that the mean of the secondary schools' scores of the 100 students is 91.400 out of 100, and the standard deviation is 5.935, while the mean of the students' first-year GPAs is 3.757, and the standard deviation is 0.719 .

Further correlational data is included in the following table:

Table 7. Correlations

\begin{tabular}{|c|c|c|c|}
\hline & & Year1 & Step \\
\hline \multirow[t]{2}{*}{ Pearson Correlation } & Year1 & 1.000 & 0.124 \\
\hline & Secondary & 0.124 & 1.000 \\
\hline \multirow[t]{2}{*}{ Sig. (1-tailed) } & Year1 & . & 0.110 \\
\hline & Secondary & 0.110 & . \\
\hline \multirow[t]{2}{*}{$\mathrm{N}$} & Year1 & 100 & 100 \\
\hline & Step & 100 & 100 \\
\hline
\end{tabular}

Table seven indicates that Pearson's correlation coefficients of students' HSGPAs and their first-year college GPAs are identical, 0.124. This shows a weak but positive relationship between students' performance in high school and college with a correlation coefficient of $(\alpha \geq 0.05)$. This value has no statistical significance since it is 0.110 , which is more significant than 0.05 . More correlational information follows in the table below:

Table 8. Model Summary ${ }^{b}$

\begin{tabular}{|l|l|l|l|l|}
\hline Model & R & R Square & Adjusted R Square & Std. the Error of the Estimate \\
\hline 1 & $0.124^{\mathrm{a}}$ & 0.015 & 0.005 & 0.7168 \\
\hline
\end{tabular}

a. Predictors: (Constant), Secondary school GPA

b. Dependent Variable: First-year college GPA

According to table eight, the correlation coefficient $₫$ is 0.124 while the square correlation coefficient is 0.015 . This indicates the ratio of variance in the dependent variable (students' firstyear GPAs), which can be predicted by the independent variable (HSGPAs). The adjusted square correlation coefficient is 0.005 , and the error of the estimate is 0.7168 . The table underneath presents variance analysis information:

Table 9. ANOVA ${ }^{a}$

\begin{tabular}{|l|l|l|l|l|l|l|}
\hline \multicolumn{2}{|l|}{ Model } & Sum of Squares & Df & Mean Square & F & Sig. \\
\hline \multirow{4}{*}{1} & Regression & 0.781 & 1 & 0.781 & 1.520 & $0.221^{\mathrm{b}}$ \\
\cline { 2 - 8 } & Residual & 50.353 & 98 & 0.514 & & \\
\cline { 2 - 7 } & Total & 51.134 & 99 & & & \\
\hline
\end{tabular}

a. Dependent Variable: First-Year College GPA

b. Predictors: (Constant), HSGPA 
Table 9 shows variance analysis which aims to investigate whether or not the regression has a statistical significance. Since the p-value is 0.221 , which is bigger than 0.05 , this indicates that the regression has no statistical significance) $\alpha \geq 0.01$ ). This finding suggests that there is no strong relationship between the dependent variable and the independent one. More regression data is in the table underneath:

\begin{tabular}{|c|c|c|c|c|c|c|}
\hline \multirow{2}{*}{\multicolumn{2}{|c|}{ Model }} & \multicolumn{2}{|c|}{ Unstandardized Coefficients } & \multirow{2}{*}{\begin{tabular}{|l|}
$\begin{array}{l}\text { Standardized } \\
\text { Coefficients }\end{array}$ \\
Beta
\end{tabular}} & \multirow[b]{2}{*}{$\mathrm{T}$} & \multirow[b]{2}{*}{ Sig. } \\
\hline & & B & $\begin{array}{l}\text { Std. } \\
\text { Error }\end{array}$ & & & \\
\hline \multirow[t]{2}{*}{1} & (Constant) & 2.389 & 1.112 & & 2.149 & 0.034 \\
\hline & Step & 0.015 & 0.012 & 0.124 & 1.233 & 0.221 \\
\hline
\end{tabular}

Dependent Variable: first-year college GPA

Table ten reveals that the constant value is 2.389 , and the independent variable coefficient $(\mathrm{X})$ is 0.015 , which means that the regression equation is:

$\mathrm{Y}=2.389+0.015(\mathrm{X})$

To further make sure that the data employed meets the conditions required when using the analysis of the linear regression, the study of residuals and graphs is utilized.

The following graph represents the regression line on/or around which appear the dots. This line is called the normal p plot.

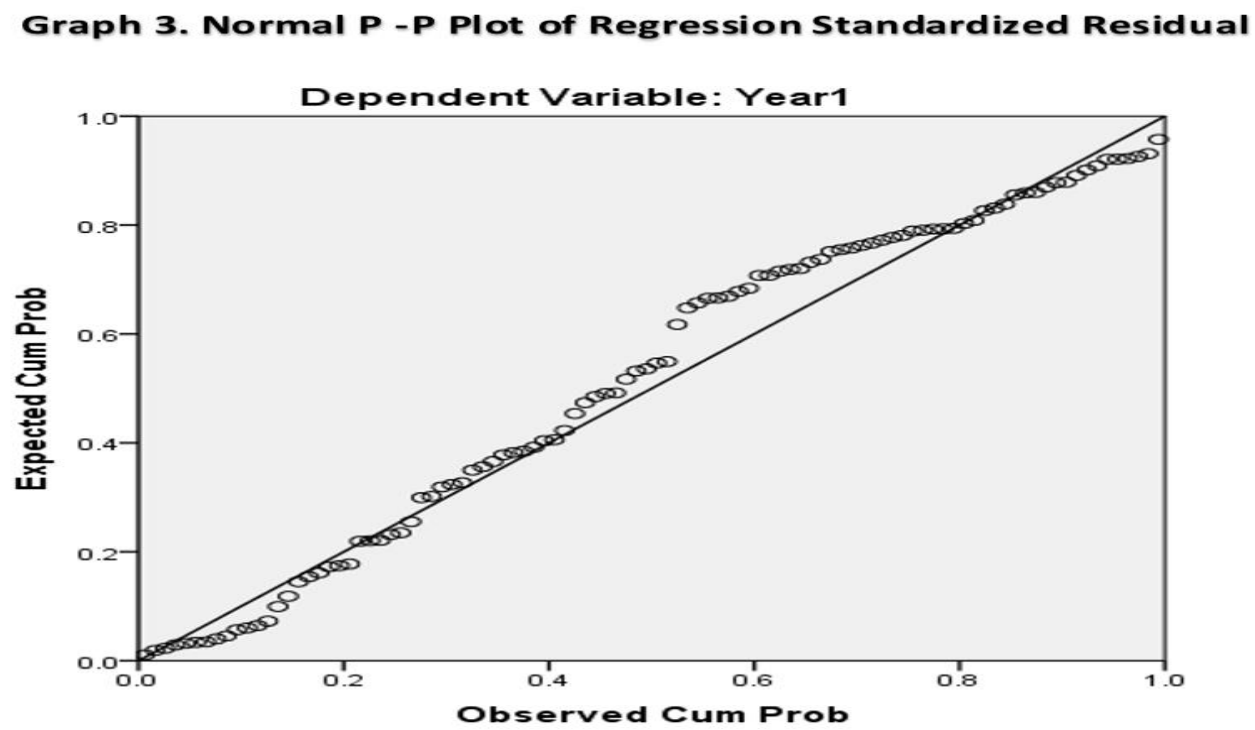

Figure 3. Observed and Expected Cum

Figure three indicates that the data gathered around the straight line, and this shows that the values of residuals have average distribution, which is a requirement for using the linear regression analysis. More data of residuals follow: 


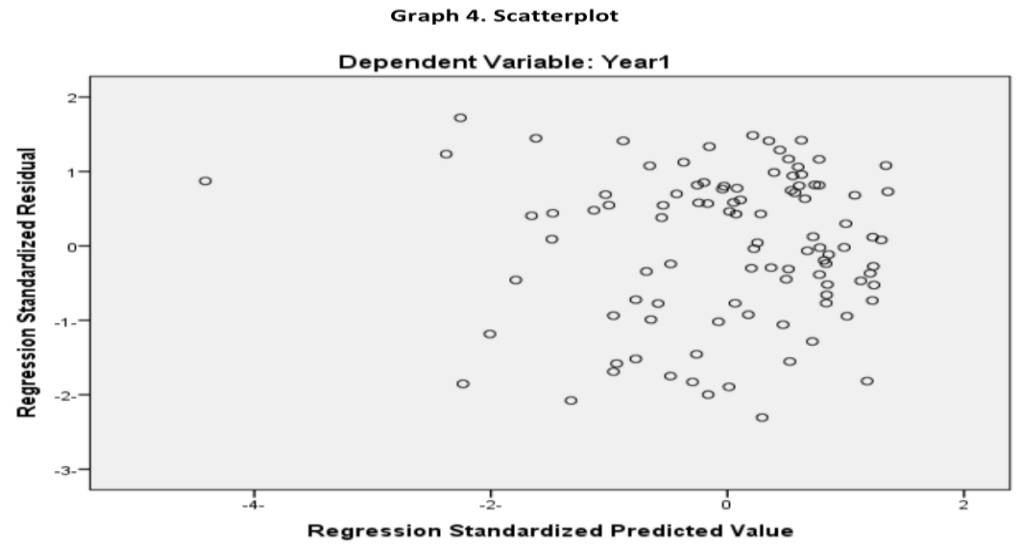

Figure 4. Regression Standardized Value 2

Figure 4 shows the residuals distribution form with the expected values. Since the distribution does not follow a specific pattern, this fulfills the linearity condition, which indicates the relationship between the dependent and independent variable. It is also worth mentioning here that random distribution of residuals with the expected values is also a requirement for linear regression.

The relationship between the type of high school and students' GPAs

This analysis is related to differences in freshmen's 1st-year college GPAs attributed to the types of secondary school they graduated from (whether public or private), $t$-test of the two samples was utilized to investigate the differences between the means of the two groups. Results are exhibited in the table11 below:

Table 11. Group Statistics

\begin{tabular}{|c|c|c|c|c|}
\hline & School & N & Mean & Std. deviation \\
\hline \multirow{2}{*}{$1^{\text {st }}$ year college GPA } & Private HS & 61 & 3.706 & 0.728 \\
\cline { 2 - 5 } & Public HS & 39 & 3.836 & 0.705 \\
\hline
\end{tabular}

As table 11 reveals, graduates of private schools are sixty-one students, and their mean is 3.706 out of five, and the standard deviation is 0.728 , while graduates of public schools are thirty-nine, and their mean is 3.836 out of five, and the standard deviation is 0.705 . More data about mean differences is underneath:

Table 12. Independent Samples Test

\begin{tabular}{|c|c|c|c|c|c|}
\hline & $\mathrm{N}$ & Mean & df & T & Sig \\
\hline Private & 61 & 3.706 & 98 & -0.881 & 0.380 \\
\hline Governmental & 39 & 3.836 & & & \\
\hline
\end{tabular}

In addition to indicating the numbers of private and public school's graduates and their means, the table above also reveals that the degree of freedom is 98 , and the $t$ value is 0.880 . The table further shows that the $\mathrm{p}$-value is 0.380 , which is more significant than 0.05 , suggesting that there are no statistical significance differences between the means of the graduates of the two high school types. 


\section{Discussion}

In this study, the predictive ability of three factors: (1) admission test, (2) high school general point average (HSGA), and (3) the type of student's high school was examined to see if they can foretell Saudi EFL students at the end of their first college year.

If this study's findings showed that students' HSGPAs and scores on Standardized Test for English Proficiency (STEP) correlate positively with students' academic attainment, admission officials should depend on these two measures as admission or placement criteria. Likewise, if the performance of private schools' graduates proved to be poor, as alleged, private HSGPAs as an admission measure, should be reconsidered.

The results of analyzing students' scores on the admissions test (STEP) suggest that they correlate positively with learners' learning success. That is, there is a strong relationship between a student's admission test score and his academic attainment at the end of first year at college.

Table two indicates that the Pearson correlation coefficient of the dependent and the independent variable is 0.399 , which reveals a high correlation between admission tests and student's performance. When considering the analysis of variance as shown in table four, it can be seen that the $\mathrm{p}$-value is 0.000 , which is less than 0.05 . This reveals that the regression has a statistical significance and shows that there is a strong relationship between students' STEP scores and their first-year college GPAs.

The linear regression result also supports the positive correlation between the dependent variable and the predictor one. As figure one reveals, data is gathering around the straight line, which suggests that the values of the residuals have natural distribution.

The results further assure the relationship between the criterion variable and the independent one in the way residuals are distributed. Since residuals do not follow a particular pattern in their distribution, this fulfills the condition of a linear relationship between the two variables in hand. The results of the relationship between the admission test and the first-year college GPA is in line with several studies (Scott-Clayton, 2012, Evans, 2012; O'Connor \& Paunonen, 2007, Adelman, 1999).

The findings of this research question go in line with a number of studies (Radunzel \& Noble, 2012, Allen \& Robbins, 2010; Allen, Robbins, Casillas, \& Oh, 2008; Noble \& Radunzel, 2007; Robbins, Allen, Casillas, Peterson, \& Le, 2006), but run contrary to other studies findings (Tracey \& Sedlacek, 1984; Levin \& Wyckoff, 1994; Burton \& Ramist, 2001).

Moving to question, two which investigates the predictive validity of high school GPAs to foresee students' performance at the end of their first year of college, the study findings reveal no significant relationship between the two variables. As the Pearson coefficients of the dependent and independent variables are identical (0.124), this reflects that the correlation coefficient of students' attainment and their high school GPAs is $(\alpha \geq 0.05)$, which has no statistical significance because it is 0.110 , which is more significant than 0.05 .

After investigating the statistical significance of the regression by analyzing the variance, as shown in table 9 , the p-value comes to be 0.221 , which is more significant than 0.05 . This means that the regression has no statistical significance $(\alpha \geq 0.05)$. Therefore, as this result suggests, 
there is no strong correlation between a Saudi student's HSGPA and his first-year performance at the college. The findings of this research question are in contrast with various studies' results which claim positive relation between students' HSGPA and first-year college attainment (Munro, 1981; Lawlor, Richman, \& Richman, 1997; Peltier, Laden, \& Martranga, 1999; Snyder, Hackett, Stewart, \& Smith, 2003; Camara \& Echternacht, 2000; Tross et al., 2000; Fleming \& Garcia, 1998; Fleming, 2002; Hoffman, 2002; Zheng et al., 2002; Gose, 1994, Rel Northwest, 2016, William C. Hiss, 2014, Geiser \& Santelices, 2007, Hiss \& Franks, 2014).

The findings of the research question three, surprisingly, refute the prevailing belief that the performance of public school's graduates out-perform the performance of private school learners at college-level study. It is repeatedly claimed that students of private high schools usually take high grades that do not mirror their actual academic level. Therefore, these students generally struggle when they join universities. However, the result of this part of the study suggests, as shown in table 11, that there are no statistical differences between the means of public and private high schools since statistical significance is 0.380 , which is more significant than 0.05 .

\title{
Conclusion
}

The purpose of this study was to investigate the predictive validity of students' high school grade point averages, admission test scores, and the type of high schools attended to foretell academic performance. The findings of this study underscore the precise value of the Standardized Test for English Proficiency as an admission criterion for predicting the likelihood of students' academic success. The study results showed a strong correlation between students' test grades and their first-year college GPAs.

The second predictive measure, High School General Point Average, seemed to be of less efficacy to predict students' future learning attainment. Therefore, admission personnel should not rely heavily on this measure as it proved to be less effective for that purpose.

Concerning the type of student' high school, the results revealed that students' performance is not highly affected by the kind of high school a student graduated from. This, however, runs contrary to the common claim that graduates of private schools struggle with their study when joining university since private schools are repeatedly alleged to overvalue students' performance and give them grades more than deserved.

Finally, based on the study findings, IMISU admission counselors should concentrate on the utilization of STEP as a decisive measure in the process of admitting incoming students to the college of languages and translation, IMISU.

\begin{abstract}
About the Author:
Alotaibi, Nayef Shaie, is an assistant professor and head of the testing unit in the English Department, College of Languages and Translations, Imam Mohammad Ibn Saud Islamic University, Riyadh, Saudi Arabia. He is interested in applied linguistics research in general and in assessment research in specific. ORCiD ID: https://orcid.org/0000-0001-9463-3770
\end{abstract}




\section{References}

ACT. (2009). National overview: Measuring college and career readiness - the class of 2009. Iowa City, IA: ACT.

Adelman, Clifford \& Clifford, (1999). Answers in the Tool Box: Academic Intensity, Attendance Patterns, and Bachelor's Degree Attainment

Ali R, Ali SK, Afzal A. (2019) Predictive validity of a Uniform Entrance Test for the health professionals. Pak J Med Sci. 35(2):330-336.

Allen, J., \& Robbins, S. (2010). Effects of interes.t-major congruence, motivation, and academic performance on timely degree attainment. Journal of Counseling Psychology, 57(1), 23- 35. doi: 10.1037/a0017267

Allen, J., Robbins, S., Casilla, A., \& Oh, I. (2008) Third-year college retention and transfer: Effects of academic performance, motivation, and social connectedness. Research in Higher Education, 49, (7), 647-664. Doi 10.1007/s11162-008-9098-3

Atkinson, R., \& Geiser, S. (Eds.). (2009). Reflections on a century of college admissions test. Berkeley, CA: University of California, Berkeley.

Bracco, S. (2014), A mathematical model for the optimal operation of the University of Genoa Smart Poly-generation Microgrid: evaluation of the technical, economic and environmental performance indicators. Science direct, 14, 912-922. DOI: 10.1016/j.energy.2013.10.039

Burton, N. W., \& Ramist, L. (2001). Predicting long term success in undergraduate school: A review of predictive validity studies. Princeton, NJ: Educational Testing Service.

Camara, W. J., \& Echternacht, G. (2000). The SAT I and high school grades: Utility in predicting success in college. College Board Research Notes (RN-10). New York: College Board.

Clayton, S. D. (2012). Environment and identity. In S. D. Clayton (Ed.), The Oxford handbook of environmental and conservation psychology (pp. 164-180). Oxford University Press. https://doi.org/10.1093/oxfordhb/9780199733026.013.0010

Clinedinst, M.E., Hurley, S.F., \& Hawkins, D.A. (2011). 2011 State of College Admission. Alexandria, VA: National Association for College Admissions Counseling.

Crede', M., \& Kuncel, N. R. (2008). Study Habits, Skills, and Attitudes: The Third Pillar Supporting Collegiate Academic Performance. Perspectives on Psychological Science, 3, (6), 425-453. https://doi.org/10.1111/j.1745-6924.2008.00089.x

Crocker, L. \& Algina, J. (1986). Introduction to Classical and Modem Test Theory. New York: Holt, Rinehart and Winston.

Dadgar, M., Collins, L., \& Schaefer, K. (2015). Placed for success: How California community colleges can improve the accuracy of placement in English and math courses, reduce remediation rates, and improve student success. Oakland, CA:

Career Ladders Project. Retrieved from:

http://www.careerladdersproject.org/wpcontent/uploads/2015/03/CLP IP Brief 37 508.pdf.

Elert, G. (1992). The SAT, aptitude or demographics? E-World. Retrieved from: http://www.hypertextbook.com/eworld/.

Fleming, J., \& Garcia, N. (1998). Are standardized tests fair to African Americans? Predictive validity of the SAT in Black and White institutions. Journal of Higher Education, 69(5), 471-495.

Geiser, S., and Santelices, M.V. (2006). "The role of Advanced Placement and honors courses in college admissions." In P. Gandara, G. Orfield \& C. Horn (Eds.), Expanding Opportunity in Higher Education (pp. 75-114). Albany, NY: SUNY Press. 
Gose, Daris A., (1994 "The Development of the Better Schools Program in Tennessee From 1981 to 1986" Electronic Theses and Dissertations. Paper 2687. https://dc.etsu.edu/etd/2687

Hawkins, R., Lantz L. (2005). From self-sufficiency to personal and family sustainability: A new paradigm for social policy. Journal of Sociology \& Social Welfare, 32(4), 77-92.

Hiss, W. C., \& Franks, V. W. (2014). Defining promise: Optional standardized testing policies in American college and university admissions. Arlington, VA: National Association for College Admission Counseling. Retrieved from: http://www.nacacnet.org/research/research-data/nacac- Research/Documents/DefiningPromise.pdf.

Hodara, M., \& Cox, M. (2016). Developmental education and college readiness at the University of Alaska (REL 2016-123). Washington, DC: U.S. Department of Education, Institute of Education Sciences, National Center for Education Evaluation and Regional Assistance, Regional Educational Laboratory Northwest. Retrieved from http://ies.ed.gov/ncee/edlabs.

Hoffman, J. L. (2002). The impact of student cocurricular involvement on student success: Racial and religious differences. Journal of College Student Development, 43(5), 712-739.

Jerald, C. D. (2009). Defining a 21 st century education. Alexandria, VA: The Center for Public Education.

Kobrin, J. L., Patterson, B. F., Shaw, E. J., Mattern, K. D., \& Barbuti, S. M. (2008). Validity of the SAT for predicting first-year college grade point average. New York: The College Board.

Lawlor, S., Richman, S., \& Richman, C. L. (1997). The validity of using the SAT as a criterion for black and white students' admission to college. College Student Journal, 31(4), 507-515.

Levin, J., \& Wyckoff, J. H. (1994). Predicting persistence and success in baccalaureate engineering. Education, 111, 461-468.

Marsh AA, Finger EC, Mitchell DG, Reid ME, Sims C, Kosson DS, Towbin KE, Leibenluft E, Pine DS, Blair RJ, (2008). Reduced amygdala response to fearful expressions in children and adolescents with callous-unemotional traits and disruptive behavior disorders. Am J Psychiatry. 2008 Jun;165(6):712-20. doi: 10.1176/appi.ajp.2007.07071145. Epub 2008 Feb 15. Erratum in: Am J Psychiatry. 2008 Jul;165(7):920. Erratum in: Am J Psychiatry. 2008 May;165(5):652. PMID: 18281412.

Mathiasen, R. E. (1984). Predicting college academic achievement: a research review. College Student Journal, 18, (4), 380-386.

Melancon, J. G. (2002). Reliability, structure, and correlates of Learning and Study Strategies Inventory scores. Educational and Psychological Measurement, 62(6), 1020-1027. doi.org/10.1177/0013164402238088

Messick, S. (1989). Validity. In R. L. Linn, (ed.), Educational Measurement (pp.13103). New York: Macmillan Publishing Company.

McPherson, M. S., \& Schapiro, M. O. (Eds.). (2008). College success: What it means and how to make it happen. New York: The College Board.

Noble, J., \& Radunzel, J. (2007). College readiness = college success beyond the first year. Paper presented at the Annual Forum of the Association for Institutional Research, June 2-6, Kansas City, Missouri.

O'Connor, M. C., \& Paunonen, S. V. (2007). Big Five personality predictors of postsecondary academic performance. Personality and Individual Differences, 43(5), 971-990. https://doi.org/10.1016/j.paid.2007.03.017 
Perfetto, G. (2002). Predicting academic success in the admissions process: Placing an empirical approach in a larger process. College Board Review, 196, 30-35.

Radunzel, J., \& Noble, J. (2012). Tracking 2003 ACT®-tested high school graduates: College readiness, enrollment, and long-term success. (ACT Research Report No. 2012-2). Iowa City, IA: ACT, Inc.

Ridgell, S. D., \& Lounsbury, J. W. (2004). Predicting academic success: General intelligence, "Big Five" personality traits, and work drive. College Student Journal, 38, (4), 607-618.

Robbins, S., Allen, J., Casillas, A., Peterson, C., \& Le, H. (2006). Unraveling the differential effects of motivational and skills, social, and self-management measures from traditional predictors of college outcomes. Journal of Educational Psychology, 98, (3), 598-616. doi.org/10.2190/CS.13.1.a

Rothstein, J. (2004), college performance prediction and the SAT, ScienceDirect, 121, 1-2, 297-317.

Sawyer, R. (2010). Usefulness of high school average and ACT scores in making college admission decisions. (ACT Research Report No. 2010-2). Iowa City, IA: ACT, Inc.

Scott-Clayton, J. (2012). Do High-Stakes Placement Exams Predict College Success? (CCRC Working Paper No. 41). New York, NY: Columbia University, Teachers College, Community College Research Center.

Scott-Clayton, J., Crosta, P. M., \& Belfield, C. R. (2014). Improving the targeting of treatment: Evidence from college remediation. Educational Evaluation \& Policy Analysis, 36(3), 371-393. http://eric.ed.gov/?id=EJ1042032.

Silva, E. (2008). Measuring skills for the 21st century. Washington, DC: Education Sector.

Tinto, V. (1993). Leaving college: Rethinking the causes and cures of student attrition. Chicago: The University of Chicago Press.

Tracey, T. J., \& Sedlacek, W. E. (1984). Noncognitive variables in predicting academic success by race. Measurement and Evaluation in Guidance, 16, 172-178.

Tross, Stuart \& Harper, JP \& Osher, LW \& Kneidinger, Linda. (2000). Not just the usual cast of characteristics: Using personality to predict college performance and retention. 41. 323-334.

Vulperhorst, J., Lutz, C., de Kleijn, R., \& van Tartwijk, J. (2018). Disentangling the predictive validity of high school grades for academic success in university. Assessment \& Evaluation in Higher Education, 43(3), 399414. https://doi.org/10.1080/02602938.2017.1353586

Westrick, P., Le, H., Robbins, S., Radunzel, J., \& Schmidt, F. (2012). "Can Do" vs. "Will Do": The Relative Effects of ACT Scores and High School GPA on College Performance and Retention. Manuscript in preparation.

Wigdor, A. K., \& Garner, W. R. (Eds.) (1982). Ability testing: Uses, consequences, and controversies. Washington, DC: National Academic.

Zeegers, P. (2001). Approaches to learning in science: A longitudinal study. British Journal of Educational Psychology, 71(1), 115132. https://doi.org/10.1348/000709901158424.

Zheng, J. L., Saunders, K. P., Shelley II, M. C., \& Whalen, D. F. (2002). Predictors of academic success for freshmen residence hall students. Journal of College Student Development, 43(2), 267-283.

Zwick, R., \& Sklar, J. (2005). Predicting college grades and degree completion using high school grades and SAT scores: The role of student ethnicity and first language. American Educational Research Journal, 42(3), 439-464. 